\title{
Agonist and antagonist effects of diadenosine tetraphosphate, a platelet dense granule constituent, on platelet P2Y1, P2Y12 and P2X1 receptors
}

\section{Citation}

Chang, Hung, Ivan B. Yanachkov, Alan D. Michelson, YouFu Li, M.R. Barnard, George E. Wright, and Andrew L. Frelinger. 2010. Agonist and Antagonist Effects of Diadenosine Tetraphosphate, a Platelet Dense Granule Constituent, on Platelet P2Y1, P2Y12 and P2X1 Receptors. Thrombosis Research 125, no. 2: 159-165. doi:10.1016/j.thromres.2009.11.006.

\section{Published Version}

doi:10.1016/j.thromres.2009.11.006

\section{Permanent link}

http://nrs.harvard.edu/urn-3:HUL.InstRepos:33776227

\section{Terms of Use}

This article was downloaded from Harvard University's DASH repository, and is made available under the terms and conditions applicable to Other Posted Material, as set forth at http:// nrs.harvard.edu/urn-3:HUL.InstRepos:dash.current.terms-of-use\#LAA

\section{Share Your Story}

The Harvard community has made this article openly available.

Please share how this access benefits you. Submit a story. 


\title{
Agonist and Antagonist Effects of Diadenosine Tetraphosphate, a Platelet Dense Granule Constituent, on Platelet P2 ${ }_{1}$, P2Y $_{12}$ and P2X 1 Receptors
}

\author{
Hung Chang ${ }^{\mathrm{a}, \mathrm{b}}$, Ivan B. Yanachkov ${ }^{\mathrm{C}}$, Alan D. Michelson ${ }^{\mathrm{a}, \mathrm{d}}$, YouFu Li ${ }^{\mathrm{a}}$, M.R. Barnard ${ }^{\mathrm{a}, \mathrm{d}}$, \\ George E. Wright ${ }^{C}$, and Andrew L. Frelinger III ${ }^{a, d}{ }^{*}$ \\ aCenter for Platelet Function Studies, Department of Pediatrics, University of Massachusetts \\ Medical School, Worcester, MA \\ bHematology Division, Chang Gung Memorial Hospital, Chang Gung University, Taipei, Taiwan \\ 'GLSynthesis Inc., Worcester, MA \\ ${ }^{d}$ Center for Platelet Research Studies, Division of Hematology/Oncology, Children's Hospital \\ Boston, Harvard Medical School, Boston, MA
}

\begin{abstract}
Introduction-Diadenosine 5 ', $5^{\prime \prime}-\mathrm{P}^{1}, \mathrm{P}^{4}$-tetraphosphate $\left(\mathrm{Ap}_{4} \mathrm{~A}\right)$ is stored in platelet dense granules, but its effects on platelet function are not well understood.

Methods and Results-We examined the effects of $\mathrm{Ap}_{4} \mathrm{~A}$ on platelet purinergic receptors $\mathrm{P}_{2} \mathrm{Y}_{1}, \mathrm{P} 2 \mathrm{Y}_{12}$ and $\mathrm{P} 2 \mathrm{X}_{1}$. Flow cytometry was used to measure the effects of $\mathrm{Ap}_{4} \mathrm{~A}$ in the presence or absence of ADP on: a) $\mathrm{P}_{2} \mathrm{Y}_{12}$-mediated decrease in intraplatelet phosphorylated vasodilator stimulated phosphoprotein (VASP), b) $\mathrm{P}_{2} \mathrm{Y}_{1}$-mediated increase in platelet cytosolic $\mathrm{Ca}^{2+}$, and c) $\mathrm{P} 2 \mathrm{X}_{1}$-mediated intraplatelet entry of extracellular $\mathrm{Ca}^{2+}$. ADP-stimulated platelet shape change $\left(\mathrm{P}_{2} \mathrm{Y}_{1}\right.$-mediated) and aggregation ( $\mathrm{P} 2 \mathrm{Y}_{1}$ - and $\mathrm{P} 2 \mathrm{Y}_{12}$-mediated) were measured optically. $\mathrm{Ap}_{4} \mathrm{~A}$ inhibited $3 \mu \mathrm{M}$ ADP-induced: a) platelet aggregation $\left(\mathrm{IC}_{50} 9.8 \pm 2.8 \mu \mathrm{M}\right)$, b) $\mathrm{P}_{2} \mathrm{Y}_{1}$-mediated shape change, c) $\mathrm{P} 2 \mathrm{Y}_{1}$-mediated increase in platelet cytosolic $\mathrm{Ca}^{2+}\left(\mathrm{IC}_{50} 40.8 \pm 12.3 \mu \mathrm{M}\right)$, and d) $\mathrm{P}_{2} \mathrm{Y}_{12-}$ mediated decrease in VASP phosphorylation $\left(\mathrm{IC}_{50}>250 \mu \mathrm{M}\right)$. In the absence of added ADP, $\mathrm{Ap}_{4} \mathrm{~A}$ had agonist effects on platelet $\mathrm{P} 2 \mathrm{X}_{1}$ and $\mathrm{P} 2 \mathrm{Y}_{12}$, but not $\mathrm{P} 2 \mathrm{Y}_{1}$, receptors.
\end{abstract}

Conclusion- $\mathrm{Ap}_{4} \mathrm{~A}$, a constituent of platelet dense granules, is a) an antagonist of platelet $\mathrm{P} 2 \mathrm{Y}_{1}$ and $\mathrm{P}_{2} \mathrm{Y}_{12}$ receptors, where it inhibits the effects of ADP, and $\mathrm{b}$ ) an agonist of platelet $\mathrm{P} 2 \mathrm{X}_{1}$ and $\mathrm{P} 2 \mathrm{Y}_{12}$ receptors.

\footnotetext{
(c) Elsevier Ltd. All rights reserved.

*Corresponding author: Andrew L. Frelinger, PhD, Children's Hospital Boston, 300 Longwood Avenue, Karp 07212, Boston, MA 02115-5737. andrew.frelinger@ childrens.harvard.edu Phone: (617) 919-2537. Fax: (617) 7304632.

Publisher's Disclaimer: This is a PDF file of an unedited manuscript that has been accepted for publication. As a service to our customers we are providing this early version of the manuscript. The manuscript will undergo copyediting, typesetting, and review of the resulting proof before it is published in its final citable form. Please note that during the production process errors may be discovered which could affect the content, and all legal disclaimers that apply to the journal pertain.

Conflict of Interests Statement

Drs. Yanachkov and Wright are employees of GLSynthesis, Inc. Drs. Michelson and Frelinger have been principal investigators on research grants to the University of Massachusetts Medical School from Arena Pharmaceuticals, GLSynthesis, Lilly/Daiichi Sankyo, and Sanofi Aventis/Bristol-Myers Squibb. Dr. Michelson has been a consultant to Lilly/Daiichi Sankyo and Sanofi Aventis/Bristol-Myers Squibb.
} 


\section{Keywords}

ADP; diadenosine tetraphosphate; platelets; purinergic receptors; platelet aggregation

\section{Introduction}

Platelets express three purinergic receptors, $\mathrm{P} 2 \mathrm{X}_{1}, \mathrm{P}_{2} \mathrm{Y}_{1}$ and $\mathrm{P} 2 \mathrm{Y}_{12}$ (Fig. 1).[1,2] $\mathrm{P} 2 \mathrm{X}_{1}$ receptors are activated by adenosine 5'-triphosphate (ATP) while $\mathrm{P}_{2} \mathrm{Y}_{1}$ and $\mathrm{P}_{2} \mathrm{Y}_{12}$ receptors are both activated by adenosine 5'-diphosphate (ADP) [1,2]. The $\mathrm{P} 2 \mathrm{X}_{1}$ receptor is a ligandgated ion channel which upon activation triggers fast influx of extracellular $\mathrm{Ca}^{2+}$ into the cytoplasm and transient platelet shape change (Fig. 1) [1-4]. $\mathrm{P}_{2} \mathrm{Y}_{1}$ and $\mathrm{P} 2 \mathrm{Y}_{12}$ are G-protein coupled receptors, $\mathrm{P} 2 \mathrm{Y}_{1}$ being coupled to $\mathrm{G}_{\mathrm{q}}$ and $\mathrm{P} 2 \mathrm{Y}_{12}$ to $\mathrm{G}_{\mathrm{i}}[1,2]$. Upon activation, $\mathrm{P} 2 \mathrm{Y}_{1}$ triggers $\mathrm{Ca}^{2+}$ mobilization from the platelet dense tubular system, shape change, and reversible platelet aggregation (Fig. 1) [1,2]. Activation of $\mathrm{P}_{2} \mathrm{Y}_{12}$ leads to inhibition of the adenylyl cyclase-dependent production of cytoplasmic cyclic adenosine 5'-monophosphate (cAMP) and propagation of stable platelet aggregation $[1,2]$. cAMP activates protein kinase A which then phosphorylates vasodilator stimulated protein (VASP) [2,5], a modulator of platelet cytosolic proteins (Fig. 1). Both $\mathrm{P}_{2} \mathrm{Y}_{1}$ and $\mathrm{P} 2 \mathrm{Y}_{12}$ play major roles in the amplification and stabilization of platelet activation. The exact physiological role of $\mathrm{P} 2 \mathrm{X}_{1}$ is less clear, but it plays a role in the enhancement of the effect of low levels of primary platelet activators and in high shear stress activation $[1,2]$.

Diadenosine $5{ }^{\prime}, 5^{\prime \prime}-\mathrm{P}^{1}, \mathrm{P}^{4}$-tetraphosphate $\left(\mathrm{Ap}_{4} \mathrm{~A}\right)$ and other diadenosine polyphosphates are naturally occurring compounds that are ubiquitous in mammalian tissues[6], including human platelets[7,8]. They may serve as neurotransmitters[9] and modulators of vascular tone [10].There is growing evidence that $\mathrm{Ap}_{4} \mathrm{~A}$ plays a role in systemic diseases such as diabetes mellitus and hypertension [11,12]. In platelets, $\mathrm{Ap}_{4} \mathrm{~A}$ is stored in dense granules, and is therefore released along with ADP and ATP upon platelet activation[8,13]. $\mathrm{Ap}_{4} \mathrm{~A}$ and its analogs are known to inhibit ADP-induced platelet activation[14,15]. $\mathrm{Ap}_{4} \mathrm{~A}$ analogs inhibit the ADP-induced platelet release reaction, calcium mobilization, thromboxane production and platelet factor 3 activities[14]. However, these studies[14,15] were performed before all three platelet purinergic receptors were cloned and their functions characterized. Therefore, the mechanism by which $\mathrm{Ap}_{4} \mathrm{~A}$ inhibits ADP-induced platelet activation and its possible effects on $\mathrm{P}_{2} \mathrm{Y}_{1}$ and $\mathrm{P} 2 \mathrm{Y}_{12}$ are unknown. Diadenosine polyphosphates are potent agonists of P2X receptors expressed on a variety of human and rat cell types[16,17]. Although human platelets express $\mathrm{P} 2 \mathrm{X}_{1}$ receptors[18-20], whether $\mathrm{Ap}_{4} \mathrm{~A}$ is an agonist via platelet $\mathrm{P} 2 \mathrm{X}_{1}$ is unknown. The goal of the present study was, therefore, to elucidate the effects of $\mathrm{Ap}_{4} \mathrm{~A}$ on signaling through $\mathrm{P}_{2} \mathrm{Y}_{1}, \mathrm{P}_{2} \mathrm{Y}_{12}$ and $\mathrm{P} 2 \mathrm{X}_{1}$ receptors on human platelets. We demonstrate that $\mathrm{Ap}_{4} \mathrm{~A}$, a known constituent of platelet dense granules, is: a) an antagonist of platelet $\mathrm{P} 2 \mathrm{Y}_{1}$ and $\mathrm{P} 2 \mathrm{Y}_{12}$ receptors, where it inhibits the effects of the agonist $\mathrm{ADP}, \mathrm{b}$ ) an agonist of $\mathrm{P} 2 \mathrm{X}_{1}$ receptors, and c) a partial agonist of $\mathrm{P}_{2} \mathrm{Y}_{12}$ receptors.

\section{Materials and Methods}

\section{Chemicals and reagents}

$\mathrm{Ap}_{4} \mathrm{~A}$ was synthesized by a novel method (to be published) and was $>98 \%$ pure by reverse phase HPLC. MRS2179, MRS2159, probenecid, adenosine 5'-( $\beta, \gamma$-methylene)triphosphate $\left(\beta, \gamma-\mathrm{CH}_{2}\right.$-ATP) and apyrase (grade VII) were purchased from Sigma-Aldrich (St. Louis, MO). D-Phenylalanyl-L-prolyl-L-arginine chloromethyl ketone (PPACK) was purchased from Calbiochem (EMD Biosciences, La Jolla, CA). FLUO-4 was from Invitrogen (Carlsbad, $\mathrm{CA}$ ), ADP was from Bio/Data (Horsham, PA), CD41-phycoerythrin (PE)-Cy5 was from Beckman Coulter (Fullerton, CA), and AR-C69931 was from AstraZeneca (Charnwood, UK). 


\section{Blood collection and sample preparation}

Human blood samples were taken from healthy volunteer donors who had been free from aspirin or other non-steroidal anti-inflammatory drugs for more than 7 days. IRB-approved written informed consent was obtained before blood collection. Unless otherwise specified, blood was drawn from antecubital veins into $3.2 \%$ sodium citrate tubes. Whole blood was used in VASP phosphorylation and $\mathrm{P}_{2} \mathrm{Y}_{1}$ cytosolic $\mathrm{Ca}^{2+}$ assays. For platelet aggregation tests, the blood was centrifuged at $110 \mathrm{~g}$ for 12 minutes and platelet-rich plasma (PRP) was immediately removed. The remaining samples were further centrifuged at $1650 \mathrm{~g}$ for 10 minutes to obtain platelet-poor plasma (PPP), which was used as a reference. For assays of platelet $\mathrm{P} 2 \mathrm{X}_{1}$ receptor functions, whole blood was drawn into tubes containing PPACK $(0.3 \mathrm{mM}$, final concentration) and apyrase (1.8 $\mu \mathrm{M}$ final concentration). The samples were then centrifuged and processed to retrieve PRP and PPP.

\section{ADP-induced platelet aggregation and shape change}

Light transmission platelet aggregation was performed as previously described[21]. ADP (3 $\mu \mathrm{M})$ in the presence or absence of various concentrations of $\mathrm{Ap}_{4} \mathrm{~A}$ was added to PRP, and the aggregation response was recorded for a total of six minutes in a Chrono-log ${ }^{\circledR}$ aggregometer running the Aggro/Link software (Chrono-log®, Havertown, PA).

For observation of ADP-induced platelet shape change, EDTA (final concentration $10 \mathrm{mM}$ ) was mixed with PRP to allow ADP-induced shape change but to avoid platelet-platelet aggregation. After obtaining a stable baseline tracing in the aggregometer ADP $(3 \mu \mathrm{M})$, in the presence or absence of various concentrations of $\mathrm{Ap}_{4} \mathrm{~A}$, was added to induce platelet shape change, and the tracing recorded for a total of 4 minutes.

\section{Platelet aggregation measured by microplate reader}

The 96-well microplate method for the detection of platelet aggregation is a simple, rapid, low volume method to simultaneously measure platelet aggregation of multiple samples, thereby avoiding the variable of platelet aging[22,23]. In brief, ADP $(5 \mu \mathrm{L}$, final concentration $3 \mu \mathrm{M})$ and $\mathrm{Ap}_{4} \mathrm{~A}(5 \mu \mathrm{L}$, at various concentrations) were added to each well of a flat bottom 96-well Immulon microplate (Thermo Fisher Scientific, Waltham, MA). PRP ( $90 \mu \mathrm{L})$ was then added to each well with a multi-channel pipette, and light transmission was recorded with a Molecular Devices microplate reader, running SOFTmax Pro 4.0 software at $580 \mathrm{~nm}$ wavelength under the kinetic mode, with intermittent shaking and readings every 11 seconds at $37^{\circ} \mathrm{C}$. Results of platelet aggregation measured by the microplate method have been demonstrated to be comparable to results of conventional platelet aggregation[22,23]. Similarly, we observed comparable $\mathrm{Ap}_{4} \mathrm{~A}$ inhibition of ADP-stimulated platelet aggregation by these two methods in the present study (Figure 2A and 2B). Since the microplate method avoids possible aging artifacts, results from this method were used to calculate the $\mathrm{IC}_{50}$ for $\mathrm{Ap}_{4} \mathrm{~A}$.

\section{P2Y 12 -mediated VASP phosphorylation assay}

VASP phosphorylation (Fig. 1) was measured by flow cytometry[5] using a kit (BioCytex, Marseilles, France) essentially according to the manufacturer's recommendations. In brief, $\mathrm{Ap}_{4} \mathrm{~A}$ or vehicle $(2 \mu \mathrm{L})$ was added to each set of assay tubes, followed by prostaglandin $\mathrm{E}_{1}$ $\left(\mathrm{PGE}_{1}, 9 \mu \mathrm{L}\right)$ or the same volume of PGE1 plus ADP. Citrated whole blood $(10 \mu \mathrm{L})$ was then added to each tube, and the samples were incubated for 10 minutes at room temperature. The samples were then fixed, permeabilized, and labeled with a fluorescently conjugated monoclonal antibody (clone 16C2) directed against the serine 239 phosphorylated form of VASP and, as a platelet identifier, CD61. Analysis was performed in a FACSCalibur flow cytometer (Becton Dickinson, Mountain View, CA). The platelet reactivity index (PRI) was calculated after subtracting background fluorescence, according to the manufacturer's 
recommendations using the formula PRI $=\left[\left(\mathrm{MFI}_{(\mathrm{PGE} 1)}-\mathrm{MFI}_{(\mathrm{PGE} 1+\mathrm{ADP})}\right) / \mathrm{MFI}_{(\mathrm{PGE} 1)}\right] \times 100$, where MFI is the mean fluorescence intensity.

HEPES-saline buffer was added as a control (i.e. no antagonist, $0 \%$ inhibition). The possible agonist property of $\mathrm{Ap}_{4} \mathrm{~A}$ on $\mathrm{P}_{2} \mathrm{Y}_{12}$ was tested by adding $\mathrm{Ap}_{4} \mathrm{~A}$ to the tube incubated with $\mathrm{PGE}_{1}$ in the absence of ADP.

To evaluate degradation and the possibility of generating biologically active metabolites of $\mathrm{Ap}_{4} \mathrm{~A}$ in the VASP assay, $\mathrm{Ap}_{4} \mathrm{~A}$ was incubated with whole blood and the $\mathrm{PGE}_{1}$ reagent from the VASP kit for 0, 3, 6 and 10 minutes. The mixture was centrifuged at 13,600 g for 1 minute and the supernatant retrieved and stored at $-80^{\circ} \mathrm{C}$ until analysis. Prior to analysis by high performance liquid chromatography (HPLC), proteins were removed by perchloric acid precipitation and the samples centrifuged $(13,000 \mathrm{~g})$ and filtered $(0.45 \mu$ nylon).

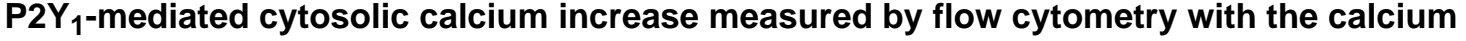 indicator FLUO-4}

The ADP-dependent, $\mathrm{P}_{2} \mathrm{Y}_{1}$-mediated increase in platelet cytosolic calcium was measured by detecting changes in FLUO-4 fluorescence (Fig. 1), as previously described[24]. In brief, one part of citrated whole blood was added to 9 parts of a loading solution consisting of FLUO-4 ( $5 \mu \mathrm{M}$ final concentration), CD41-PE-Cy5 (1:176 dilution in HEPES-saline buffer [10 mM HEPES, $0.15 \mathrm{M} \mathrm{NaCl}, \mathrm{pH} 7.4]$ ) and probenecid (1 mM final concentration), and the mixture was incubated for 30 minutes at room temperature. Fifteen $\mu \mathrm{L}$ of this mixture were added to $525 \mu \mathrm{L}$ of HEPES-saline buffer, and the mixture analyzed by a FACSCalibur flow cytometer. After obtaining a 30 second baseline recording, the acquisition was paused, and $60 \mu \mathrm{L}$ of either $\operatorname{ADP}\left(3 \mu \mathrm{M}\right.$ final concentration), $\mathrm{Ap}_{4} \mathrm{~A}$ at various concentrations, or $\mathrm{ADP}(3 \mu \mathrm{M}$ final concentration) plus $\mathrm{Ap}_{4} \mathrm{~A}$ at various concentrations were quickly added, the sample mixed, and the acquisition resumed (total pause time less than 10 seconds). FLUO-4 fluorescence was monitored for a total of 2 minutes. FLUO-4 fluorescence was plotted vs. time using FlowJo version 7.2.2 (Tree Star, Ashland, OR) software. The mean FLUO-4 fluorescence of the baseline 30 second interval and of 10 second post-stimulant intervals were calculated. The cytosolic $\mathrm{Ca}^{2+}$ increase was calculated as the ratio of the maximal post-stimulant FLUO-4 fluorescence to the baseline FLUO-4 fluorescence. The percent inhibition of ADP-induced calcium increase due to the addition of $\mathrm{Ap}_{4} \mathrm{~A}$ was calculated relative to $\mathrm{ADP}(3 \mu \mathrm{M})$ plus vehicle (HEPES-saline).

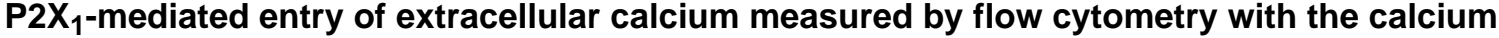 indicator FLUO-4}

$\mathrm{P} 2 \mathrm{X}_{1}$ receptors are ligand-gated ion channels which, when triggered, cause cytosolic $\mathrm{Ca}^{2+}$ to increase by allowing entry of extracellular $\mathrm{Ca}^{2+}$ (Fig. 1). Measurement of $\mathrm{P} 2 \mathrm{X}_{1}$-mediated entry of extracellular $\mathrm{Ca}^{2+}$ with FLUO-4 differed from measurement of $\mathrm{P}_{2} \mathrm{Y}_{1}$-mediated increase in cytosolic $\mathrm{Ca}^{2+}$ from intracellular stores in that 1$)$ blood was collected in PPACK $(0.3 \mathrm{mM})$ rather than sodium citrate, to preserve physiologic extracellular $\mathrm{Ca}^{2+}$ levels, 2) apyrase (1.8 $\mu \mathrm{M}$ final concentration) was added immediately upon blood collection to degrade any ATP present, thereby avoiding $\mathrm{P} 2 \mathrm{X}_{1}$ receptor desensitization.[1,25], 3) prior to loading platelets with FLUO-4, PRP was separated from erythrocytes in order to minimize erythrocyte-derived nucleotides, and 4) FLUO-4-loaded platelets were diluted and analyzed in buffer containing $\mathrm{Ca}^{2+}(2 \mathrm{mM})$ rather than in $\mathrm{Ca}^{2+}$-free buffer to provide physiologic levels of extracellular $\mathrm{Ca}^{2+}$. Platelets in apyrase-treated, PPACK-anticoagulated PRP were loaded with FLUO-4 for 30 minutes in the presence of probenecid $(1 \mathrm{mM})$, diluted in HEPES-saline buffer containing $2 \mathrm{mM} \mathrm{CaCl}_{2}$, and then baseline FLUO-4 fluorescence was obtained. P2 $\mathrm{X}_{1}$-dependent entry of extracellular $\mathrm{Ca}^{2+}$ was demonstrated by increased FLUO-4 fluorescence upon addition of the specific $\mathrm{P} 2 \mathrm{X}_{1}$ receptor agonist $\beta, \gamma-\mathrm{CH}_{2}-\mathrm{ATP}(20 \mu \mathrm{M})$, and the absence of this increase when 
platelets were resuspended in $1 \mathrm{mM}$ EGTA, HEPES-saline buffer, or prepared without addition of apyrase to preserve $\mathrm{P} 2 \mathrm{X}_{1}$ activity. FLUO-4 fluorescence after addition of various concentrations of $\mathrm{Ap}_{4} \mathrm{~A}$ to this system was used to evaluate agonist activity on $\mathrm{P} 2 \mathrm{X}_{1}$. In addition, the ability of $\mathrm{Ap}_{4} \mathrm{~A}(50 \mu \mathrm{M})$ to block P2X $\mathrm{X}_{1}$ activation by $\beta, \gamma-\mathrm{CH}_{2}-\mathrm{ATP}(20 \mu \mathrm{M})$ was tested. To ensure that the increase of cytosolic $\mathrm{Ca}^{2+}$ in these experiments was not due to spurious $\mathrm{P}_{2} \mathrm{Y}_{1}$-mediated $\mathrm{Ca}^{2+}$ increase, some experiments were done in the presence of $1 \mathrm{mM}$ EGTA in HEPES-saline buffer, MRS2179 $\left(100 \mu \mathrm{M}\right.$, a P2 $\mathrm{Y}_{1}$ receptor antagonist),[26,27] or both.

\section{Statistical analysis}

The results were analyzed by GraphPad Prism software, version 4.00 for Windows (GraphPad Software, San Diego, CA). All results are expressed as mean \pm standard error of the mean (SEM). Student's t-test was used to determine statistical significance when two groups of data were compared. One way ANOVA and Bonferroni's multiple comparison test were used when three or more groups of data were compared.

\section{Results}

\section{Inhibition of ADP-induced platelet aggregation}

$\mathrm{Ap}_{4} \mathrm{~A}$ inhibited maximal ADP-induced platelet aggregation and, at a high concentration (100 $\mu \mathrm{M}$ ), prevented secondary aggregation and resulted in disaggregation (Fig. 2A). Dosedependent inhibition of ADP-induced platelet aggregation determined by the 96-well microplate method is shown in Fig. $2 \mathrm{~B}$. The $\mathrm{IC}_{50}$ was $9.8 \pm 2.8 \mu \mathrm{M}$.

\section{Agonist and antagonist properties of $\mathrm{Ap}_{4} \mathrm{~A}$ on $\mathrm{P}_{2} \mathrm{Y}_{12}$ receptors}

The unstimulated baseline VASP phosphorylation MFI was obtained by treating platelets with PGE1 in all experiments (Fig. 3). As expected, the addition of $3 \mu \mathrm{M}$ ADP reduced VASP phosphorylation (Fig. 3, open bar). Ap 4 A was added to attenuate this ADP effect as a potential antagonist (in comparison with $\mathrm{PGE}_{1}+\mathrm{ADP}$ ) or to reduce VASP phosphorylation by itself as a potential agonist (in comparison with $\mathrm{PGE}_{1}$ alone). VASP phosphorylation in the presence of $15.6 \mu \mathrm{M} \mathrm{Ap} \mathrm{A}_{4} \mathrm{~A}$ (Fig. 3, hash-marked grey bar) was significantly reduced compared to that obtained with $\mathrm{PGE}_{1}$ alone (Fig. 3, grey bar, $\mathrm{p}<0.01$ ), suggesting that $\mathrm{Ap}_{4} \mathrm{~A}$ acts as an agonist of $\mathrm{P}_{2} \mathrm{Y}_{12}$. However, increasing the concentration of $\mathrm{Ap}_{4} \mathrm{~A}$ up to $250 \mu \mathrm{M}$ did not further reduce $\mathrm{PGE}_{1}$-stimulated VASP phosphorylation ( $\mathrm{p}>0.05$ for the comparison among three $\mathrm{Ap}_{4} \mathrm{~A}$ concentrations tested), suggesting that $\mathrm{Ap}_{4} \mathrm{~A}$ is only a partial agonist of $\mathrm{P}_{2} \mathrm{Y}_{12}$. Addition of the specific P2 $\mathrm{Y}_{12}$ antagonist AR-C69931 $(10 \mu \mathrm{M})$ blocked Ap 4 A-induced reduction of VASP phosphorylation (data not shown), indicating that this agonist effect of $\mathrm{Ap}_{4} \mathrm{~A}$ is mediated through $\mathrm{P}_{2} \mathrm{Y}_{12}$. HPLC analysis of $\mathrm{Ap}_{4} \mathrm{~A}$ incubated with whole blood under the same conditions used in the VASP assay for up to $10 \mathrm{~min}$ (i.e., the incubation time of the VASP assay) showed no loss of $\mathrm{Ap}_{4} \mathrm{~A}$ (data not shown). Likewise, the normal degradation products of $\mathrm{Ap}_{4} \mathrm{~A}$, AMP and ATP, were low and did not increase over time and ADP was not detected (data not shown). Thus, the agonist effect of $\mathrm{Ap}_{4} \mathrm{~A}$ on $\mathrm{P}_{2} \mathrm{Y}_{12}$ did not appear to be mediated by a metabolite of $\mathrm{Ap}_{4} \mathrm{~A}$.

In the presence of increasing concentrations of $\mathrm{Ap}_{4} \mathrm{~A}$, there was a dose-dependent blockade of ADP's effect, resulting in higher levels of phosphorylated VASP (Fig. 3, hash-marked open bars). The calculated PRI for the inhibition of VASP phosphorylation induced by ADP relative to the maximal VASP phosphorylation without ADP was $89.5 \pm 2.1 \%, 74.7 \pm 1.0 \%, 61.5 \pm$ $9.4 \%$, and $48.9 \pm 6.2 \%$ for $0,15.6,62.5$, and $250 \mu \mathrm{M} \mathrm{Ap} 4 \mathrm{~A}$, respectively. Thus, the $\mathrm{IC}_{50}$ for $\mathrm{Ap}_{4} \mathrm{~A}$ inhibition of the ADP-induced, $\mathrm{P}_{2} \mathrm{Y}_{12}$-mediated response was $>250 \mu \mathrm{M}$. 


\section{Agonist and antagonist properties of $\mathrm{Ap}_{4} \mathrm{~A}$ on $\mathrm{P}_{2} \mathrm{Y}_{1}$ receptors}

ADP stimulation of $\mathrm{P}_{2} \mathrm{Y}_{1}$ results in platelet shape change which can be measured by the change in transmittance in an aggregometer. $\mathrm{Ap}_{4} \mathrm{~A}$ inhibited $3 \mu \mathrm{M}$ ADP-induced platelet shape change in a dose-dependent manner (Fig. 4A, estimated $\mathrm{IC}_{50} 200 \mu \mathrm{M}$ ). ADP stimulation of P2 $\mathrm{Y}_{1}$ also results in increases in cytosolic $\mathrm{Ca}^{2+}$ (Fig. 1). Therefore, we evaluated the effect of $\mathrm{Ap}_{4} \mathrm{~A}$ on the ADP-induced increase in cytoplasmic $\mathrm{Ca}^{2+}$. In platelets prepared in the absence of apyrase, i.e. without preserving the activity of $\mathrm{P} 2 \mathrm{X}_{1}$, and without addition of extracellular $\mathrm{Ca}^{2+}, 3 \mu \mathrm{M}$ ADP produced an approximately 3.5 -fold increase in FLUO-4 fluorescence and this increase was inhibited by $\mathrm{Ap}_{4} \mathrm{~A}$ in a dose-dependent manner (Fig. 4B), with an $\mathrm{IC}_{50}$ of $40.8 \pm 12.3 \mu \mathrm{M}$. That a higher concentration of $\mathrm{Ap}_{4} \mathrm{~A}$ was required for 50\% inhibition $\mathrm{ADP}$-stimulated platelet shape change $(\sim 200 \mu \mathrm{M})$ than was required for inhibition of ADP-stimulated increase in cytoplasmic $\mathrm{Ca}^{2+}$ from intracellular stores $(\sim 40 \mu \mathrm{M})$ is not surprising since platelet shape change is likely triggered by a low threshold increase in cytoplasmic $\mathrm{Ca}^{2+}$, and thus would require an amount of $\mathrm{Ap}_{4} \mathrm{~A}$ that reduces the cytoplasmic $\mathrm{Ca}^{2+}$ increase by greater than $50 \%$. Thus, as evidenced by two independent assays, platelet shape change and increase in cytosolic $\mathrm{Ca}^{2+}, \mathrm{Ap}_{4} \mathrm{~A}$ is an antagonist of $\mathrm{P}_{2} \mathrm{Y}_{1}$ receptors.

Under the same conditions, but in the absence of ADP, $\mathrm{Ap}_{4} \mathrm{~A}$ at concentrations up to $250 \mu \mathrm{M}$ did not induce an increase in cytoplasmic $\mathrm{Ca}^{+2}$ as measured by the FLUO-4 fluorescence ratio in comparison with HEPES-saline vehicle control $(1.18 \pm 0.09$ vs. $1.09 \pm 0.06$, mean \pm SEM, $\mathrm{n}=5, \mathrm{p}=0.161)$. Thus, $\mathrm{Ap}_{4} \mathrm{~A}$ is not an agonist of $\mathrm{P}_{2} \mathrm{Y}_{1}$.

\section{Agonist and antagonist properties of $\mathrm{Ap}_{4} \mathrm{~A}$ on $\mathrm{P} 2 \mathrm{X}_{1}$ receptors}

Platelet $\mathrm{P} 2 \mathrm{X}_{1}$ function was not a factor in the platelet aggregation, shape change, $\mathrm{P} 2 \mathrm{Y}_{1}$ release of internal $\mathrm{Ca}^{2+}$, and $\mathrm{P}_{2} \mathrm{Y}_{12}$-mediated VASP assays described above since activity of $\mathrm{P}_{2} \mathrm{X}_{1}$ was not preserved under the conditions used to isolate platelets for those assays. However, when platelets were prepared using protocols to protect $\mathrm{P} 2 \mathrm{X}_{1}$ from desensitization and suspended in buffer containing $2 \mathrm{mM} \mathrm{Ca}^{2+}, \mathrm{Ap}_{4} \mathrm{~A}$ at $0.1 \mu \mathrm{M}$ and higher concentrations induced an increase in platelet intracellular $\mathrm{Ca}^{2+}$ (Fig. 5A). For Ap 4 A concentrations between 0.1 and $10 \mu \mathrm{M}$, this increase was entirely due to the $\mathrm{P} 2 \mathrm{X}_{1}$-mediated entry of extracellular $\mathrm{Ca}^{2+}$, because it was eliminated when platelets were resuspended in buffer containing EGTA instead of $\mathrm{Ca}^{2+}$ (Fig. 5). Moreover, failure of the $\mathrm{P}_{2} \mathrm{Y}_{1}$ antagonist MRS2179 at $100 \mu \mathrm{M}$ to inhibit the $\mathrm{Ap}_{4} \mathrm{~A}$-stimulated rise in $\mathrm{Ca}^{2+}$ (Fig. 5A) indicated that this rise was not due to direct or indirect stimulation of $\mathrm{P}_{2} \mathrm{Y}_{1}$. Similarly, the majority of the cytoplasmic $\mathrm{Ca}^{2+}$ rise produced by $50 \mu \mathrm{M}$ $\mathrm{Ap}_{4} \mathrm{~A}$ was eliminated in the presence of EGTA and could not be blocked by MRS2179.

However, there was a small, but statistically significant component of the $\mathrm{Ca}^{2+}$ increase at 50 $\mu \mathrm{M} \mathrm{Ap}{ }_{4} \mathrm{~A}$ that was not blocked by EGTA but was blocked by MRS2179, indicating some $\mathrm{P}_{2} \mathrm{Y}_{1}$-mediated contribution at this high $\mathrm{Ap}_{4} \mathrm{~A}$ concentration. The biphasic dose-response observed for $\mathrm{Ap}_{4} \mathrm{~A}$ (Fig. 5A) was also observed with the specific $\mathrm{P}_{2} \mathrm{X}_{1}$ receptor agonist $\beta, \gamma-$ $\mathrm{CH}_{2}$-ATP (data not shown). Finally, MRS2159, a selective P2X $\mathrm{X}_{1}$ antagonist [28], added in parallel with $\mathrm{Ap}_{4} \mathrm{~A}$, dose-dependently blocked $\mathrm{Ap}_{4} \mathrm{~A}$-stimulated $\mathrm{Ca}^{2+}$ entry into platelets (Fig. 6 ), demonstrating that the $\mathrm{Ap}_{4} \mathrm{~A}$-induced rise in platelet cytoplasmic $\mathrm{Ca}^{2+}$ requires $\mathrm{P}_{2} \mathrm{X}_{1}$. Taken together, these data show that $\mathrm{Ap}_{4} \mathrm{~A}$ is an agonist of platelet $\mathrm{P} 2 \mathrm{X}_{1}$ receptors.

When $50 \mu \mathrm{M} \mathrm{Ap}{ }_{4} \mathrm{~A}$ was added to a submaximal concentration of a selective $\mathrm{P} 2 \mathrm{X}_{1}$ agonist, 20 $\mu \mathrm{M} \beta, \gamma-\mathrm{CH}_{2}$-ATP, the post-stimulation FLUO-4 MFI was higher than with $20 \mu \mathrm{M} \beta, \gamma-\mathrm{CH}_{2}-$ ATP alone $(4.43 \pm 0.20 v s .3 .57 \pm 0.47, \mathrm{p}=0.034, \mathrm{n}=3)$. Thus, there was no evidence that $\mathrm{Ap}_{4} \mathrm{~A}$ is a $\mathrm{P} 2 \mathrm{X}_{1}$ antagonist, and the enhanced response suggested that $\mathrm{Ap}_{4} \mathrm{~A}$ augmented the P2 $\mathrm{X}_{1}$ agonist effect of $20 \mu \mathrm{M} \beta, \gamma-\mathrm{CH}_{2}$-ATP. 


\section{Discussion}

The major findings of this study are that $\mathrm{Ap}_{4} \mathrm{~A}$, a known constituent of platelet dense granules, is: a) an antagonist of platelet $\mathrm{P}_{2} \mathrm{Y}_{1}$ and $\mathrm{P} 2 \mathrm{Y}_{12}$ receptors, where it inhibits the effects of the agonist $\mathrm{ADP}, \mathrm{b}$ ) an agonist of $\mathrm{P} 2 \mathrm{X}_{1}$ receptors, and c) a partial agonist of $\mathrm{P}_{2} \mathrm{Y}_{12}$ receptors. These stimulating and inhibiting activities are summarized in Table 1.

\section{Antagonist effects of $A p_{4} A$ on platelet $P 2 Y_{1}$ and $P 2 Y_{12}$ receptors}

Previously published studies showed that $\mathrm{Ap}_{4} \mathrm{~A}$ and its analogs inhibit ADP-induced platelet aggregation and several aspects of platelet activation including release action, cytoplasmic calcium mobilization, thromboxane production, fibrinogen binding, and platelet factor 3 activities[14]. This inhibition of platelet functions was considered to be mediated through the $\mathrm{P}_{2 \mathrm{~T}}$ pathway[14], a poorly defined term used before the currently known purinergic receptors, $\mathrm{P} 2 \mathrm{X}_{1}, \mathrm{P}_{2} \mathrm{Y}_{1}$ and $\mathrm{P} 2 \mathrm{Y}_{12}$, were cloned and their functions well characterized. In the current study, consistent with these previous reports [14], we found that $\mathrm{Ap}_{4} \mathrm{~A}$ inhibits $3 \mu \mathrm{M}$ ADPinduced platelet aggregation. The platelet disaggregation that was observed with $100 \mu \mathrm{M}$ $\mathrm{Ap}_{4} \mathrm{~A}$ (Fig. 2) suggests that $\mathrm{Ap}_{4} \mathrm{~A}$ inhibited the $\mathrm{P}_{2} \mathrm{Y}_{12}$ pathway. On the other hand, we also found that $\mathrm{Ap}_{4} \mathrm{~A}$ inhibits $3 \mu \mathrm{M}$ ADP-induced platelet shape change (Fig. $4 \mathrm{~A}$ ), which is mainly mediated by $\mathrm{P} 2 \mathrm{Y}_{1}[1,25]$.

ADP-induced platelet signaling through $\mathrm{P}_{2} \mathrm{Y}_{1}$ and $\mathrm{P} 2 \mathrm{Y}_{12}$ receptors can be examined by specific assays, i.e. ADP-induced calcium increase for $\mathrm{P}_{2} \mathrm{Y}_{1}$ receptors and ADP-induced VASP phosphorylation decrease for $\mathrm{P}_{2} \mathrm{Y}_{12}$ receptors (Fig. 1). In the present study, $3 \mu \mathrm{M}$ ADPinduced platelet cytosolic $\mathrm{Ca}^{2+}$ rise was inhibited by $\mathrm{Ap}_{4} \mathrm{~A}$ with an $\mathrm{IC}_{50}$ of $40.8 \mu \mathrm{M}$ (Fig. 4B). This result confirmed that $\mathrm{Ap}_{4} \mathrm{~A}$ is a $\mathrm{P}_{2} \mathrm{Y}_{1}$ antagonist. In addition, the decrease in $\mathrm{ADP}$-induced VASP phosphorylation was inhibited by $\mathrm{Ap}_{4} \mathrm{~A}$ in a dose-dependent manner (Fig. 3). While $\mathrm{Ap}_{4} \mathrm{~A}$ inhibition of ADP-stimulated, $\mathrm{P}_{2} \mathrm{Y}_{1}$-mediated increase in cytosolic calcium was measured within seconds of adding $\mathrm{Ap}_{4} \mathrm{~A}$ and ADP to cells, the $\mathrm{P} 2 \mathrm{Y}_{12}$ mediated VASP response was measured 10 minutes after adding $\mathrm{Ap}_{4} \mathrm{~A}$ to whole blood, raising the possibility that metabolites of $\mathrm{Ap}_{4} \mathrm{~A}$, and not $\mathrm{Ap}_{4} \mathrm{~A}$ per se may be responsible for effects on $\mathrm{P} 2 \mathrm{Y}_{12}$. However, this appears unlikely since HPLC analysis showed no breakdown of $\mathrm{Ap}_{4} \mathrm{~A}$ when incubated under VASP assay conditions. Taken together, these results indicate that $\mathrm{Ap}_{4} \mathrm{~A}$ is an antagonist for both $\mathrm{P}_{2} \mathrm{Y}_{1}$ and $\mathrm{P}_{2} \mathrm{Y}_{12}$ receptors. Such dual specificity on platelet $\mathrm{P} 2 \mathrm{Y}_{1}$ and $\mathrm{P}_{2} \mathrm{Y}_{12}$ receptors has been recently reported for other compounds[29,30].

Although $3 \mu \mathrm{M}$ ADP was used as the stimulant in all experiments, the $\mathrm{IC}_{50}$ for inhibition of platelet aggregation $(9.8 \pm 2.8 \mu \mathrm{M})$ was 4 -fold lower than the $\mathrm{IC}_{50}$ for the inhibition of the $\mathrm{P}_{2} \mathrm{Y}_{1}$-mediated increase of cytosolic $\mathrm{Ca}^{2+}(40.8 \pm 12.3 \mu \mathrm{M})$ and more than 25 -fold lower than the $\mathrm{IC}_{50}$ for the $\mathrm{P}_{2} \mathrm{Y}_{12}$-mediated decrease in VASP phosphorylation $(>250 \mu \mathrm{M})$. Our results are similar to the findings of Cattaneo et al. [29] who reported that both MRS2298 and MRS2496 inhibited ADP-induced platelet aggregation, shape change and P2Y $\mathrm{Y}_{1}$-mediated $\mathrm{Ca}^{2+}$ increase but, at higher concentrations, these compounds also partially inhibited ADPinduced decrease of cAMP, possibly via the $\mathrm{P}_{2} \mathrm{Y}_{12}$ pathway. Furthermore, Cattaneo et al. [29] reported that the $\mathrm{IC}_{50}$ S of MRS2298 and MRS2496 for inhibition of platelet aggregation were lower than those for cytosolic $\mathrm{Ca}^{2+}$ increase and shape change. These data suggest synergism between $\mathrm{P}_{2} \mathrm{Y}_{1}$ and $\mathrm{P}_{2} \mathrm{Y}_{12}$ antagonism. Indeed, the synergism of antagonism between $\mathrm{P}_{2} \mathrm{Y}_{1}$ and $\mathrm{P} 2 \mathrm{Y}_{12}$ receptors using selective antagonists for each receptor has been well documented in vitro[31]. The present findings and those of Cattaneo et al.[29] demonstrate that synergism of inhibition may occur for a single compound with dual receptor antagonist properties. However, the present findings are the first report of an endogenous molecule released by platelets that has a dual and synergistic inhibitory effect on both $\mathrm{P}_{2} \mathrm{Y}_{1}$ and $\mathrm{P}_{2} \mathrm{Y}_{12}$ receptors. This synergism may be explained, at least in part, by the recently reported reciprocal cross-talk between $\mathrm{P}_{2} \mathrm{Y}_{1}$ and $\mathrm{P}_{2} \mathrm{Y}_{12}$ receptors[32,33]. 


\section{Agonist effects of $A p_{4} A$ on platelet $P 2 Y_{12}$ but not $P 2 Y_{1}$ receptors}

In addition to the inhibitory effects of $\mathrm{Ap}_{4} \mathrm{~A}$ on $\mathrm{P}_{2} \mathrm{Y}_{1}$ and $\mathrm{P} 2 \mathrm{Y}_{12}$ pathways, we demonstrated that $\mathrm{Ap}_{4} \mathrm{~A}$ attenuated PGE1-stimulated VASP phosphorylation (Fig. 3). This attenuation was prevented by AR-C69931, demonstrating specificity for $\mathrm{P}_{2} \mathrm{Y}_{12}$. These data indicates that $\mathrm{Ap}_{4} \mathrm{~A}$ either directly or indirectly (e.g., via metabolites) results in platelet $\mathrm{P} 2 \mathrm{Y}_{12}$ activation. However, our study of metabolites after incubation with whole blood suggests such effects result directly from $\mathrm{Ap}_{4} \mathrm{~A}$ rather than its metabolites.

The apparently opposing effects of $\mathrm{Ap}_{4} \mathrm{~A}$, as a weak agonist of $\mathrm{P}_{2} \mathrm{Y}_{12}$, causing a decrease in VASP phosphorylation, and at the same time as a partial antagonist of $\mathrm{P}_{2} \mathrm{Y}_{12}$, blocking ADPstimulated decrease in VASP phosphorylation are both explained by a weak and inefficient interaction of $\mathrm{Ap}_{4} \mathrm{~A}$ with $\mathrm{P}_{2} \mathrm{Y}_{12}$. When added alone, the effect of $\mathrm{Ap}_{4} \mathrm{~A}$ on VASP phosphorylation is maximal at $15.6 \mu \mathrm{M}$, suggesting saturation of $\mathrm{Ap}_{4} \mathrm{~A}$ binding to $\mathrm{P}_{2} \mathrm{Y}_{12}$ at this $\mathrm{Ap}_{4} \mathrm{~A}$ concentration and higher. However, even with saturating concentrations of $\mathrm{Ap}_{4} \mathrm{~A}$, only small decreases in VASP phosphorylation were observed, indicating the $\mathrm{Ap}_{4} \mathrm{~A}-\mathrm{P} 2 \mathrm{Y}_{12}$ interaction triggers only a weak downstream signal. In contrast, ADP by itself causes a large decrease in VASP phosphorylation, suggesting efficient coupling of ADP-P2 $\mathrm{Y}_{12}$ with downstream events. Thus, the interaction of $\mathrm{Ap}_{4} \mathrm{~A}$ with $\mathrm{P}_{2} \mathrm{Y}_{12}$, while causing weak downstream signals, prevents ADP from triggering stronger signals with larger decreases in VASP phosphorylation. The fact that very high concentrations of $\mathrm{Ap}_{4} \mathrm{~A}(250 \mu \mathrm{M})$ are required to block the ADP effect on VASP suggests that $\mathrm{Ap}_{4} \mathrm{~A}$ binding is reversible and that even binding of small amounts of ADP, as might occur over the 10 minute VASP assay incubation is sufficient to trigger a strong $\mathrm{P}_{2} \mathrm{Y}_{12}$ coupled response.

Although $\mathrm{Ap}_{4} \mathrm{~A}$ and other diadenosine polyphosphates have been reported to activate $\mathrm{P} 2 \mathrm{Y}_{1}$ receptors in other cell types[34,35], their agonist activity on platelet $\mathrm{P}_{2} \mathrm{Y}_{1}$ receptors is unknown. We found that $\mathrm{Ap}_{4} \mathrm{~A}$ stimulation did not result in $\mathrm{P}_{2} \mathrm{Y}_{1}$-mediated increase of platelet cytosolic $\mathrm{Ca}^{2+}$ and, therefore, does not act as a platelet $\mathrm{P} 2 \mathrm{Y}_{1}$ receptor agonist.

\section{Agonist effects of $A p_{4} A$ on platelet $P 2 X_{1}$ receptors}

It is well known that $\mathrm{Ap}_{4} \mathrm{~A}$ is an agonist for $\mathrm{P} 2 \mathrm{X}$ receptors in rat vas deferens and human urinary bladders[17,36]. In platelets, Sage et al. $[4]$ showed that $\mathrm{Ap}_{4} \mathrm{~A}$ may induce a rise in cytosolic $\mathrm{Ca}^{2+}$ and suggested that this was mediated by $\mathrm{P} 2 \mathrm{X}_{1}$. Such an $\mathrm{Ap}_{4} \mathrm{~A}$-induced platelet cytosolic $\mathrm{Ca}^{2+}$ rise was also observed in our study with extracellular $\mathrm{Ca}^{2+}$ available, but was obliterated when extracellular $\mathrm{Ca}^{2+}$ was removed by the chelating agent EGTA (Fig. 5A). These data confirm that the cytosolic $\mathrm{Ca}^{2+}$ increase resulted solely from an influx of extracellular $\mathrm{Ca}^{2+}$, i.e. a P2X-mediated effect (Fig. 1). Moreover, MRS2159, a selective $\mathrm{P} 2 \mathrm{X}_{1}$ antagonist[28], blocked the $\mathrm{Ap}_{4} \mathrm{~A}$-induced influx of extracellular $\mathrm{Ca}^{2+}$, demonstrating $\mathrm{Ap}_{4} \mathrm{~A}$ is a platelet $\mathrm{P} 2 \mathrm{X}_{1}$ agonist. Although $\mathrm{Ap}_{4} \mathrm{~A}$ and other adenosine polyphosphates can be both agonists and antagonists of $\mathrm{P} 2 \mathrm{Y}_{1}$ and $\mathrm{P} 2 \mathrm{Y}_{12}$ receptors, the present study has demonstrated that $\mathrm{Ap}_{4} \mathrm{~A}$ functions only as an agonist, not an antagonist, for platelet $\mathrm{P} 2 \mathrm{X}_{1}$ receptors.

\section{Possible pathophysiologic roles of $\mathrm{Ap}_{4} \mathrm{~A}$}

The plasma concentration of $\mathrm{Ap}_{4} \mathrm{~A}$ has been reported to range from $0.33-1.0 \mu \mathrm{M}[8,10,13]$. However, in the platelet-rich microenvironment where a thrombus is formed or high shear force is generated by vessel damage, the local concentration of $\mathrm{Ap}_{4} \mathrm{~A}$ may reach up to $100 \mu \mathrm{M}$ as a result of dense granule release by involved platelets $[8,10,13]$. The present study has demonstrated that $0.1-1 \mu \mathrm{M} \mathrm{Ap} 4 \mathrm{~A}$ has significant agonist effects on platelet $\mathrm{P} 2 \mathrm{X}_{1}$ receptors. In addition, $\mathrm{Ap}_{4} \mathrm{~A}$ inhibits $\mathrm{ADP}$-induced aggregation and cytosolic $\mathrm{Ca}^{2+}$ increase with $\mathrm{IC}_{50} \mathrm{~S}$ of $9.8 \pm 2.8$ and $40.8 \pm 12.3 \mu \mathrm{M}$, respectively. Although the concentrations of $\mathrm{Ap}_{4} \mathrm{~A}$ required to antagonize ADP effects on platelet $\mathrm{P}_{2} \mathrm{Y}_{1}$ and $\mathrm{P}_{2} \mathrm{Y}_{12}$ receptors are high compared to ADP, it is well known that $\mathrm{Ap}_{4} \mathrm{~A}$ and other diadenosine polyphosphates are more stable than ADP 
and ATP[10]. Whereas ADP is rapidly inactivated by ecto-nucleotidase[37], $\mathrm{Ap}_{4} \mathrm{~A}$ is more resistant to hydrolysis[10] and therefore attains higher concentrations than ADP in plasma and in the local thrombotic microenvironment. Whether this high concentration can be reached in any pathophysiological conditions is unclear therefore the pathophysiologic role of high concentration $\mathrm{Ap}_{4} \mathrm{~A}$ is speculative.

\section{Pharmacologic Perspectives}

$\mathrm{Ap}_{4} \mathrm{~A}$ is the backbone of some chemical derivatives being developed as potential antiplatelet agents. In vitro antiplatelet[14,38] and in vivo antithrombotic effects[39,40] of $\mathrm{Ap}_{4} \mathrm{~A}$ and its derivatives have been reported, and antithrombotic potency is improved after certain chemical structure modifications[14,38]. The current study shows that $\mathrm{Ap}_{4} \mathrm{~A}$ has antagonist effects for platelet $\mathrm{P} 2 \mathrm{Y}_{12}$ receptors, the target of several effective antithrombotic agents including clopidogrel and prasugrel[41]. $\mathrm{Ap}_{4} \mathrm{~A}$ derivatives, while different in potencies and selectivity towards platelet receptors (results to be published), may have antiplatelet effects comparable to clinically available drugs such as clopidogrel. In clinical studies[5], standard doses of the widely-used, FDA-approved P2Y 12 antagonist clopidogrel reduced VASP PRI to $61.1 \pm 17 \%$ mean $\pm \mathrm{SD}$ ) of maximal. In the present study, $62.5 \mu \mathrm{M} \mathrm{Ap}_{4} \mathrm{~A}$ resulted in a similar reduction of VASP PRI, to $61.5 \pm 9.4 \%$. Thus, $\mathrm{Ap}_{4} \mathrm{~A}$ released as a result of initial platelet activation may block subsequent activation of platelets to the same degree as pharmacological doses of clopidogrel. Furthermore, in the present study $250 \mu \mathrm{M} \mathrm{Ap} 4$ A reduced VASP PRI to $48.9 \pm$ $6.2 \%$.

The potential advantage of $\mathrm{Ap}_{4} \mathrm{~A}$ and its derivatives as therapeutic antiplatelet agents is that, unlike clopidogrel, prasugrel, or other $\mathrm{P}_{2} \mathrm{Y}_{12}$ antagonist in development, they also have, as demonstrated in the present study, a synergistic inhibitory effect on platelet $\mathrm{P}_{2} \mathrm{Y}_{1}$ receptors. One potential concern of using $\mathrm{Ap}_{4} \mathrm{~A}$ or its derivatives as antithrombotic agents might be their action on platelet $\mathrm{P} 2 \mathrm{X}_{1}$ receptors. Recent studies indicate that $\mathrm{P} 2 \mathrm{X}_{1}$ has an important role in platelet activation, particularly under conditions of shear stress[19]. Nevertheless, the present study on the mechanism of platelet inhibition by $\mathrm{Ap}_{4} \mathrm{~A}$ provides a framework for future development of $\mathrm{Ap}_{4} \mathrm{~A}$-derived antiplatelet agents. Chemically modified $\mathrm{Ap}_{4} \mathrm{~A}$ derivatives may be compared to $\mathrm{Ap}_{4} \mathrm{~A}$ for their selective potency on platelet purinergic receptors.

\section{Acknowledgments}

We thank Milka Yanachkova, Edward Dix and Laura Montville for the stability studies of bis-nucleoside polyphosphates in plasma. This study was funded in part by NIH SBIR grants HL081992 and HL088828.

\section{References}

1. Kahner BN, Shankar H, Murugappan S, Prasad GL, Kunapuli SP. Nucleotide receptor signaling in platelets. J Thromb Haemost 2006;4:2317-2326. [PubMed: 17059469]

2. Cattaneo, M. The platelet P2 receptors. In: Michelson, AD., editor. Platelets. 2nd edition. San Diego, CA: Elsevier/Academic Press; 2007. p. 201-220.

3. Rolf MG, Brearley CA, Mahaut-Smith MP. Platelet shape change evoked by selective activation of P2 $X_{1}$ purinoceptors with alpha,beta-methylene ATP. Thromb Haemost 2001;85:303-308. [PubMed: 11246552]

4. Sage SO, MacKenzie AB, Jenner S, Mahaut-Smith MP. Purinoceptor-evoked calcium signalling in human platelets. Prostagland Leuk Essent Fatty Acids 1997;57:435-438.

5. Aleil B, Ravanat C, Cazenave JP, Rochoux G, Heitz A, Gachet C. Flow cytometric analysis of intraplatelet VASP phosphorylation for the detection of clopidogrel resistance in patients with ischemic cardiovascular diseases. J Thromb Haemost 2005;3:85-92. [PubMed: 15634270] 
6. Rapaport E, Zamecnik PC. Presence of diadenosine 5',5"'- $\mathrm{P}^{1}, \mathrm{P}^{4}$-tetraphosphate $\left(\mathrm{Ap}_{4} \mathrm{~A}\right)$ in mammalian cells in levels varying widely with proliferative activity of the tissue: a possible positive "pleiotypic activator". Proc Natl Acad Sci U S A 1976;73:3984-3988. [PubMed: 1069282]

7. Flodgaard H, Klenow H. Abundant amounts of diadenosine 5',5"'-P1,P4-tetraphosphate are present and releasable, but metabolically inactive, in human platelets. Biochem J 1982;208:737-742. [PubMed: 6299279]

8. Luthje J, Ogilvie A. The presence of diadenosine 5',5"'- $\mathrm{P}^{1}, \mathrm{P}^{3}$-triphosphate $\left(\mathrm{Ap}_{3} \mathrm{~A}\right)$ in human platelets. Biochem Biophys Res Commun 1983;115:253-260. [PubMed: 6311204]

9. Pintor J, az-Hernandez M, Gualix J, Gomez-Villafuertes R, Hernando F, Miras-Portugal MT. Diadenosine polyphosphate receptors. from rat and guinea-pig brain to human nervous system. Pharmacol Ther 2000;87:103-115. [PubMed: 11007994]

10. Flores NA, Stavrou BM, Sheridan DJ. The effects of diadenosine polyphosphates on the cardiovascular system. Cardiovasc Res 1999;42:15-26. [PubMed: 10434992]

11. Hollah P, Hausberg M, Kosch M, Barenbrock M, Letzel M, Schlatter E, Rahn KH. A novel assay for determination of diadenosine polyphosphates in human platelets: studies in normotensive subjects and in patients with essential hypertension. J Hypertens 2001;19:237-245. [PubMed: 11212966]

12. Schluter H, Tepel M, Zidek W. Vascular actions of diadenosine phosphates. J Auton Pharmacol 1996;16:357-362. [PubMed: 9131416]

13. Jankowski J, Jankowski V, Laufer U, van der GM, Henning L, Tepel M, Zidek W, Schluter H. Identification and quantification of diadenosine polyphosphate concentrations in human plasma. Arterioscler Thromb Vasc Biol 2003;23:1231-1238. [PubMed: 12738682]

14. Chan SW, Gallo SJ, Kim BK, Guo MJ, Blackburn GM, Zamecnik PC. $\mathrm{P}^{1}, \mathrm{P}^{4}$-dithio- $\mathrm{P}^{2}, \mathrm{P}^{3}$ monochloromethylene diadenosine 5',5"'- $\mathrm{P}^{1}, \mathrm{P}^{4}$-tetraphosphate: a novel antiplatelet agent. Proc Natl Acad Sci U S A 1997;94:4034-4039. [PubMed: 9108100]

15. Harrison MJ, Brossmer R. Inhibition of platelet aggregation and the platelet release reaction by $\alpha, \omega$ diadenosine polyphosphates. FEBS Lett 1975;54:57-60. [PubMed: 1132495]

16. Lewis CJ, Gitterman DP, Schluter H, Evans RJ. Effects of diadenosine polyphosphates (Ap $\mathrm{As}$ ) and adenosine polyphospho guanosines $\left(\mathrm{Ap}_{\mathrm{n}} \mathrm{Gs}\right)$ on rat mesenteric artery $\mathrm{P} 2 \mathrm{X}$ receptor ion channels. $\mathrm{Br}$ J Pharmacol 2000;129:124-130. [PubMed: 10694211]

17. Westfall TD, McIntyre CA, Obeid S, Bowes J, Kennedy C, Sneddon P. The interaction of diadenosine polyphosphates with $\mathrm{P}_{2} \mathrm{X}$-receptors in the guinea-pig isolated vas deferens. $\mathrm{Br} \mathrm{J}$ Pharmacol 1997;121:57-62. [PubMed: 9146887]

18. MacKenzie AB, Mahaut-Smith MP, Sage SO. Activation of receptor-operated cation channels via $\mathrm{P}_{2} \mathrm{X}_{1}$ not $\mathrm{P} 2 \mathrm{~T}$ purinoceptors in human platelets. J Biol Chem 1996;271:2879-2881. [PubMed: 8621673]

19. Mahaut-Smith MP, Tolhurst G, Evans RJ. Emerging roles for $\mathrm{P} 2 \mathrm{X}_{1}$ receptors in platelet activation. Platelets 2004;15:131-144. [PubMed: 15203715]

20. Vial C, Hechler B, Leon C, Cazenave JP, Gachet C. Presence of $\mathrm{P} 2 \mathrm{X}_{1}$ purinoceptors in human platelets and megakaryoblastic cell lines. Thromb Haemost 1997;78:1500-1504. [PubMed: 9423802]

21. Born GVR. Aggregation of blood platelets by adenosine diphosphate and its reversal. Nature 1962;194:927-929. [PubMed: 13871375]

22. Bednar B, Condra C, Gould RJ, Connolly TM. Platelet aggregation monitored in a 96 well microplate reader is useful for evaluation of platelet agonists and antagonists. Thromb Res 1995;77:453-463. [PubMed: 7778060]

23. Fratantoni JC, Poindexter BJ. Measuring platelet aggregation with microplate reader. A new technical approach to platelet aggregation studies. Am J Clin Pathol 1990;94:613-617. [PubMed: 2239825]

24. do Céu MM, Sansonetty F, Gonçalves MJ, O'Connor J-E. Flow cytometric kinetic assay of calcium mobilization in whole blood platelets using Fluo-3 and CD41. Cytometry 1999;35:302-310. [PubMed: 10213195]

25. Jin J, Daniel JL, Kunapuli SP. Molecular basis for ADP-induced platelet activation. II. The P2Y 1 receptor mediates ADP-induced intracellular calcium mobilization and shape change in platelets. J Biol Chem 1998;273:2030-2034. [PubMed: 9442040] 
26. Baurand A, Raboisson P, Freund M, Leon C, Cazenave JP, Bourguignon JJ, Gachet C. Inhibition of platelet function by administration of MRS2179, a P2 $Y_{1}$ receptor antagonist. Eur J Pharmacol 2001;412:213-221. [PubMed: 11166284]

27. Boyer JL, Mohanram A, Camaioni E, Jacobson KA, Harden TK. Competitive and selective antagonism of P2Y1 receptors by N6-methyl 2'-deoxyadenosine 3',5'-bisphosphate. Br J Pharmacol 1998;124:1-3. [PubMed: 9630335]

28. Kim YC, Camaioni E, Ziganshin AU, Ji XD, King BF, Wildman SS, Rychkov A, Yoburn J, Kim H, Mohanram A, Harden K, Boyer JL, Burnstock G, Jacobson KA. Synthesis and structure-activity relationships of pyridoxal-6-arylazo-5'-phosphate and phosphonate derivatives as $\mathrm{P} 2$ receptor antagonists. Drug Dev Res 1998;45:52-66.

29. Cattaneo M, Lecchi A, Ohno M, Joshi BV, Besada P, Tchilibon S, Lombardi R, Bischofberger N, Harden TK, Jacobson KA. Antiaggregatory activity in human platelets of potent antagonists of the P2Y 1 receptor. Biochem Pharmacol 2004;68:1995-2002. [PubMed: 15476670]

30. Manolopoulos P, Glenn JR, Fox SC, May JA, Dovlatova NL, Tang SW, Thomas NR, Ralevic V, Heptinstall S. Acyl derivatives of coenzyme A inhibit platelet function via antagonism at P2Y1 and P2Y12 receptors: a new finding that may influence the design of anti-thrombotic agents. Platelets 2008;19:134-145. [PubMed: 18297551]

31. Nylander S, Mattsson C, Ramstrom S, Lindahl TL. Synergistic action between inhibition of P2 $\mathrm{Y}_{12} /$ $\mathrm{P}_{2} \mathrm{Y}_{1}$ and $\mathrm{P}_{2} \mathrm{Y}_{12}$ /thrombin in ADP- and thrombin-induced human platelet activation. Br J Pharmacol 2004;142:1325-1331. [PubMed: 15265806]

32. Tolhurst G, Vial C, Leon C, Gachet C, Evans RJ, Mahaut-Smith MP. Interplay between P2Y, $\mathrm{P}_{2} \mathrm{Y}_{12}$, and $\mathrm{P} 2 \mathrm{X}_{1}$ receptors in the activation of megakaryocyte cation influx currents by ADP: evidence that the primary megakaryocyte represents a fully functional model of platelet P2 receptor signaling. Blood 2005;106:1644-1651. [PubMed: 15914557]

33. Hardy AR, Jones ML, Mundell SJ, Poole AW. Reciprocal cross-talk between P2Y 1 and P2 $Y_{12}$ receptors at the level of calcium signaling in human platelets. Blood 2004;104:1745-1752. [PubMed: 15187029]

34. Schachter JB, Li Q, Boyer JL, Nicholas RA, Harden TK. Second messenger cascade specificity and pharmacological selectivity of the human P2Y1-purinoceptor. Br J Pharmacol 1996;118:167-173. [PubMed: 8733591]

35. Patel K, Barnes A, Camacho J, Paterson C, Boughtflower R, Cousens D, Marshall F. Activity of diadenosine polyphosphates at P2Y receptors stably expressed in 1321N1 cells. Eur J Pharmacol 2001;430:203-210. [PubMed: 11711032]

36. Bianchi BR, Lynch KJ, Touma E, Niforatos W, Burgard EC, Alexander KM, Park HS, Yu H, Metzger R, Kowaluk E, Jarvis MF, van BT. Pharmacological characterization of recombinant human and rat P2X receptor subtypes. Eur J Pharmacol 1999;376:127-138. [PubMed: 10440098]

37. Marcus AJ, Broekman MJ, Drosopoulos JH, Islam N, Pinsky DJ, Sesti C, Levi R. Metabolic control of excessive extracellular nucleotide accumulation by CD39/ecto-nucleotidase-1: implications for ischemic vascular diseases. Journal of Pharmacology \& Experimental Therapeutics 2003;305:9-16. [PubMed: 12649347]

38. Zamecnik PC, Kim B, Gao MJ, Taylor G, Blackburn GM. Analogues of diadenosine 5',5"'-P' $\mathrm{P}^{1} \mathrm{P}^{4}$ tetraphosphate $\left(\mathrm{Ap}_{4} \mathrm{~A}\right)$ as potential anti-platelet-aggregation agents. Proc Natl Acad Sci U S A 1992;89:2370-2373. [PubMed: 1549600]

39. Louie S, Kim BK, Zamecnik P. Diadenosine 5',5"'- $\mathrm{P}^{1}, \mathrm{P}^{4}$-tetraphosphate, a potential antithrombotic agent. Thromb Res 1988;49:557-565. [PubMed: 3388311]

40. Kim BK, Zamecnik P, Taylor G, Guo MJ, Blackburn GM. Antithrombotic effect of $\beta, \beta^{\prime}-$ monochloromethylene diadenosine 5 ', $5^{\prime \prime}-\mathrm{P}^{1}, \mathrm{P}^{4}$-tetraphosphate. Proc Natl Acad Sci U S A 1992;89:11056-11058. [PubMed: 1438314]

41. Michelson A. P2Y 12 antagonism: promises and challenges. Arterioscler Thromb Vasc Biol 2008;28:s33-s38. [PubMed: 18174449] 


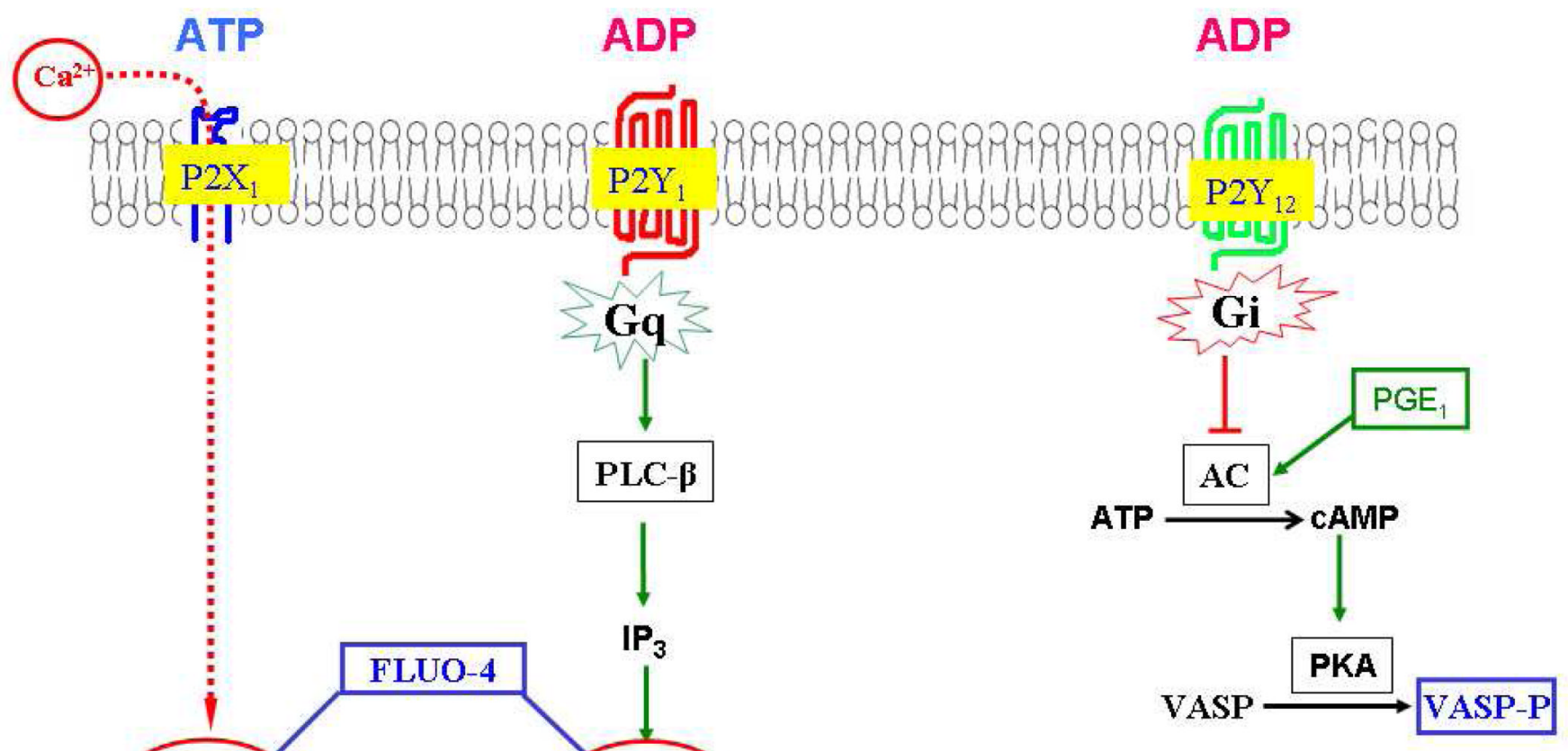

The ligand is ADP for $\mathrm{P}_{2} \mathrm{Y}_{1}$ and $\mathrm{P} 2 \mathrm{Y}_{12}$, and ATP for $\mathrm{P} 2 \mathrm{X}_{1}$. $\mathrm{P} 2 \mathrm{X}_{1}$ is a ligand-gated ion channel which allows extracellular $\mathrm{Ca}^{2+}$ to shift into the cytoplasm upon activation. ADP binding to the $\mathrm{P}_{2} \mathrm{Y}_{1}$ receptor induces activation of phospholipase $\mathrm{C} \beta$ (PLC- $\beta$ ), which, via inositol triphosphate $\left(\mathrm{IP}_{3}\right)$, subsequently leads to release of cytoplasmic $\mathrm{Ca}^{2+}$ pools. Both $\mathrm{P} 2 \mathrm{X}_{1}$ and $\mathrm{P}_{2} \mathrm{Y}_{1}$ activation cause cytosolic $\mathrm{Ca}^{2+}$ increase, which in the present study was measured by flow cytometry with the $\mathrm{Ca}^{2+}$ indicator, FLUO-4. ADP binding to platelet $\mathrm{P}_{2} \mathrm{Y}_{12}$ receptors results in a decrease of cytoplasmic cAMP by inhibiting adenylyl cyclase. cAMP subsequently leads, via protein kinase A (PKA), to phosphorylation of vasodilator stimulated phosphoprotein (VASP), which was measured by flow cytometry. 

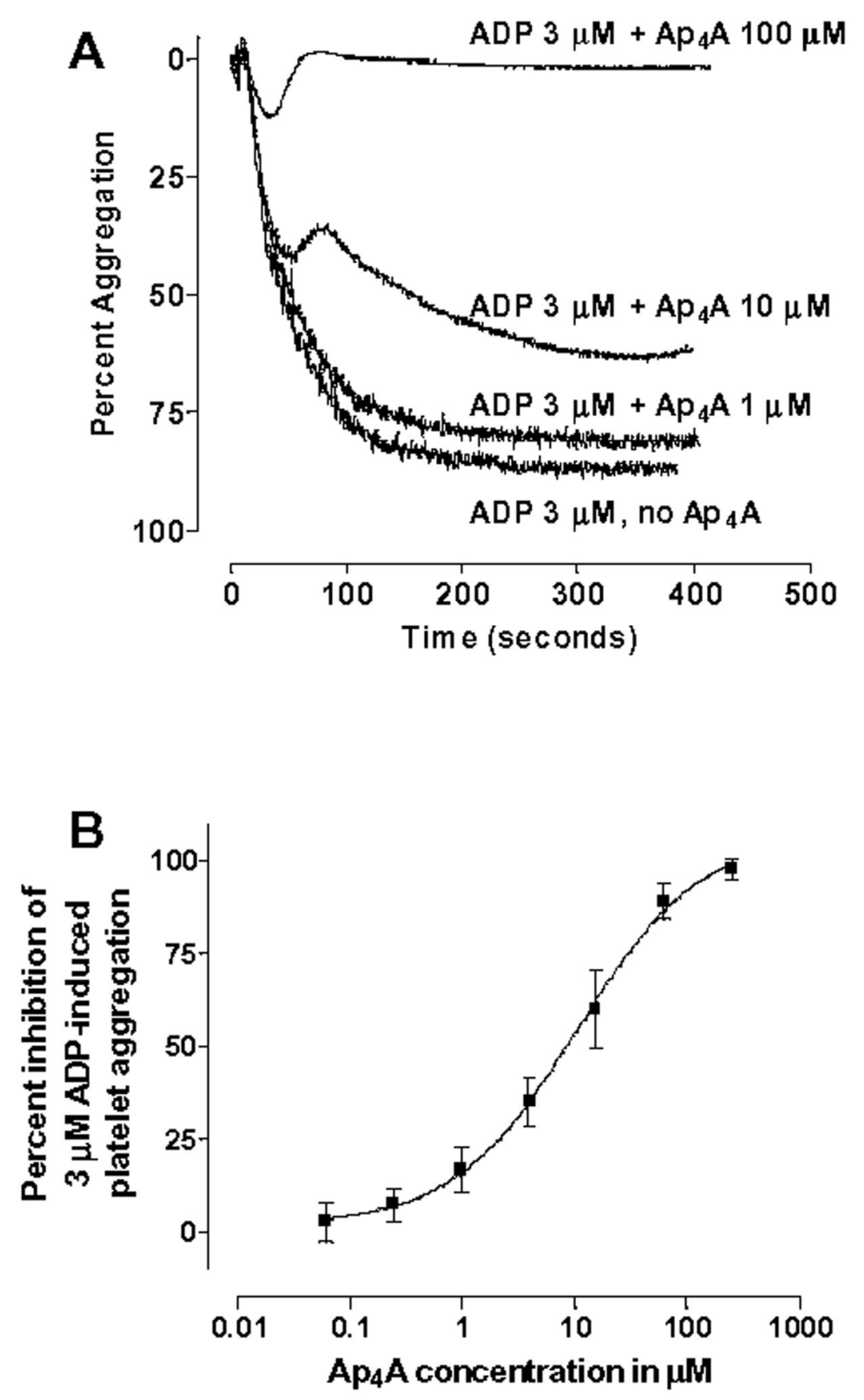

Figure 2. Ap4A inhibits ADP-induced platelet aggregation $\mathrm{A}$, Platelet aggregation induced by $3 \mu \mathrm{M}$ ADP was inhibited by $\mathrm{Ap}_{4} \mathrm{~A}$ in a dose-dependent manner. At $100 \mu \mathrm{M} \mathrm{Ap} 4 \mathrm{~A}$ complete platelet disaggregation was observed. The experiments were performed in a Chrono- $\log ®$ aggregometer. $\mathrm{B}$, Dose response curve for $\mathrm{Ap}_{4} \mathrm{~A}$ inhibition of $3 \mu \mathrm{M}$ ADP-induced platelet aggregation (mean $\pm \mathrm{SEM}, \mathrm{n}=3$ ). The results were obtained with the 96-well microplate reader method. 


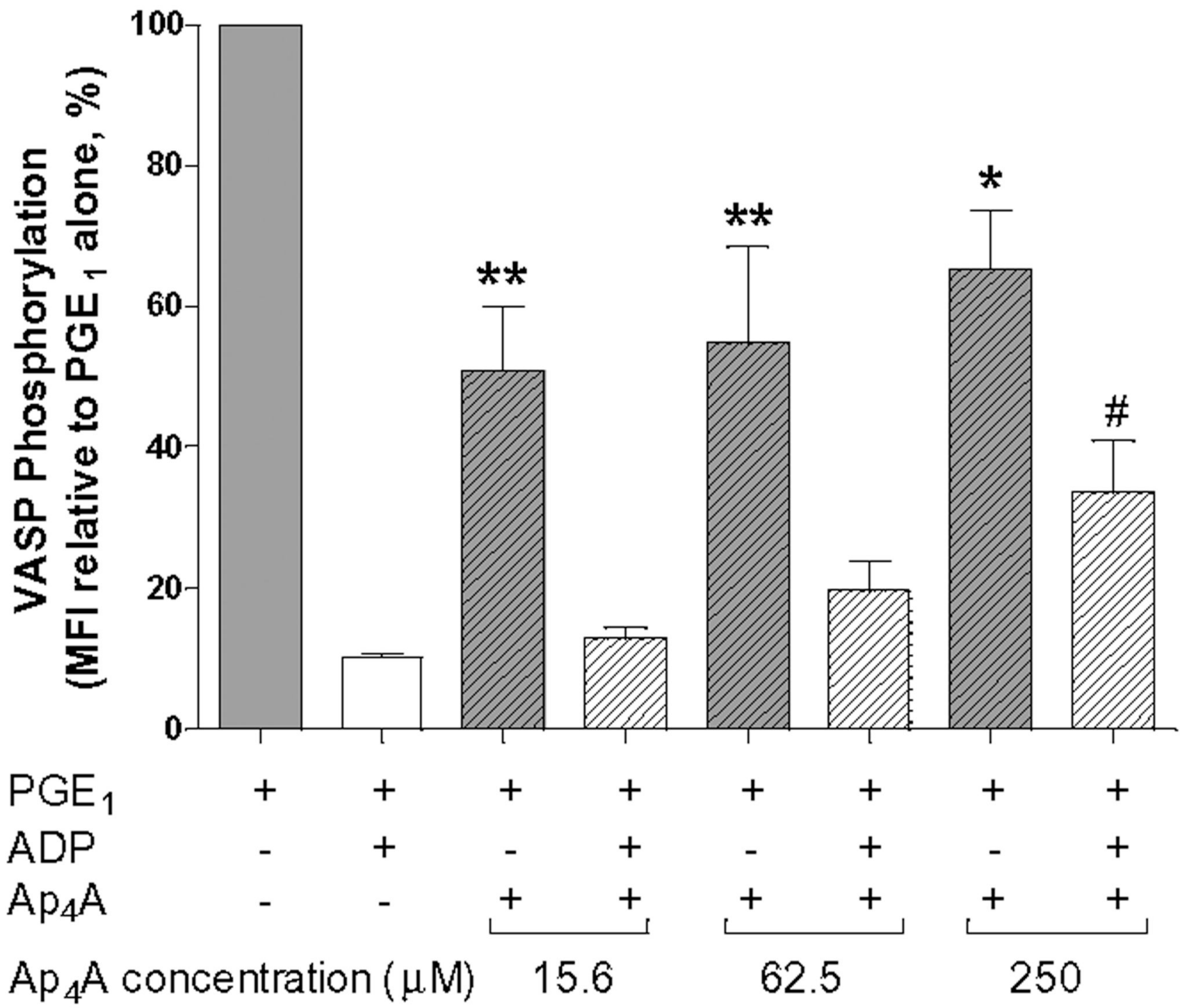

Figure 3. Ap4 A reduces VASP phosphorylation and attenuates the ADP-induced decrease in VASP phosphorylation

Platelets were treated with $\mathrm{PGE}_{1}$ in every experiment, and the resultant MFI was used as unstimulated baseline (see Materials and Methods for details). As expected, the addition of 3 $\mu \mathrm{M}$ ADP reduced VASP phosphorylation (open bar). This ADP-induced decrease in VASP phosphorylation was attenuated by $\mathrm{Ap}_{4} \mathrm{~A}$ in a dose dependent manner (hash-marked open bars), \# $\mathrm{p}<0.05$ compared with $\mathrm{PGE}_{1}$ plus ADP (open bar). $\mathrm{Ap}_{4} \mathrm{~A}$ in the absence of ADP addition resulted in a decrease in VASP phosphorylation but not in a dose-dependent manner (hashmarked grey bars, $* \mathrm{p}<0.05, * * \mathrm{p}<0.01$ compared with $\mathrm{PGE}_{1}$ alone. There was no statistically significant difference among the three tested concentrations of $\mathrm{Ap}_{4} \mathrm{~A}$. The data (mean $\pm \mathrm{SEM}$, $n=3$ ) were analyzed by one way ANOVA and Bonferroni's multiple comparison test. 

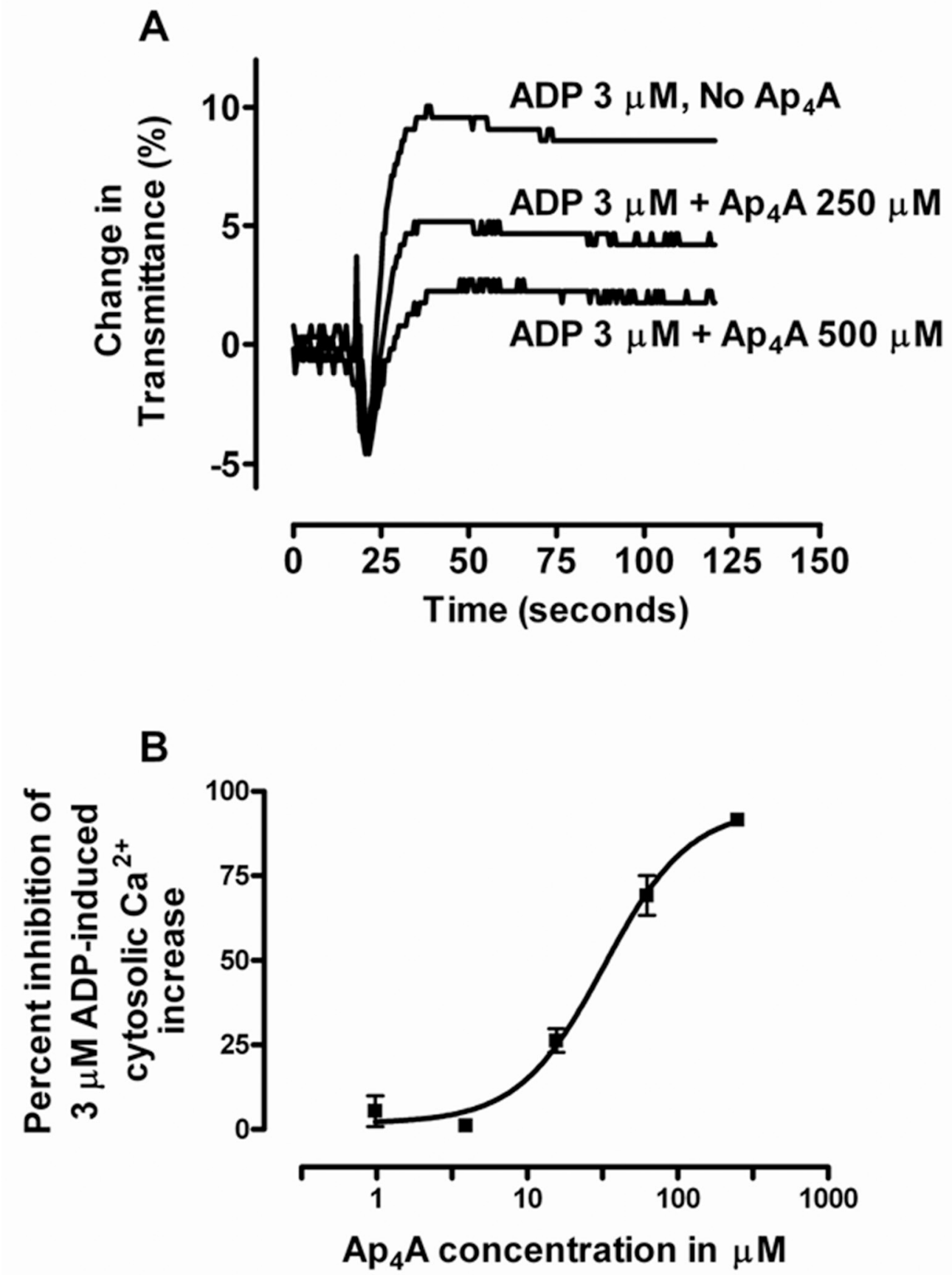

Figure 4. Ap4A inhibits ADP-induced platelet shape change and cytosolic $\mathrm{Ca}^{2+}$ increase $\mathrm{A}$, Platelet shape change (upward deflection) induced by $3 \mu \mathrm{M}$ ADP was inhibited by $\mathrm{Ap}_{4} \mathrm{~A}$ in a dose-dependent manner. Note that there was no platelet aggregation (downward deflection) after shape change because EDTA $(10 \mathrm{mM})$ was mixed with PRP. Results shown are representative of 3 such experiments. B, Dose response curve of $\mathrm{Ap}_{4} \mathrm{~A}$ inhibition of $3 \mu \mathrm{M}$ ADP-induced intracellular $\mathrm{Ca}^{2+}$ increase, measured by flow cytometry with the calcium indicator FLUO-4 (mean \pm SEM, $n=4)$. 


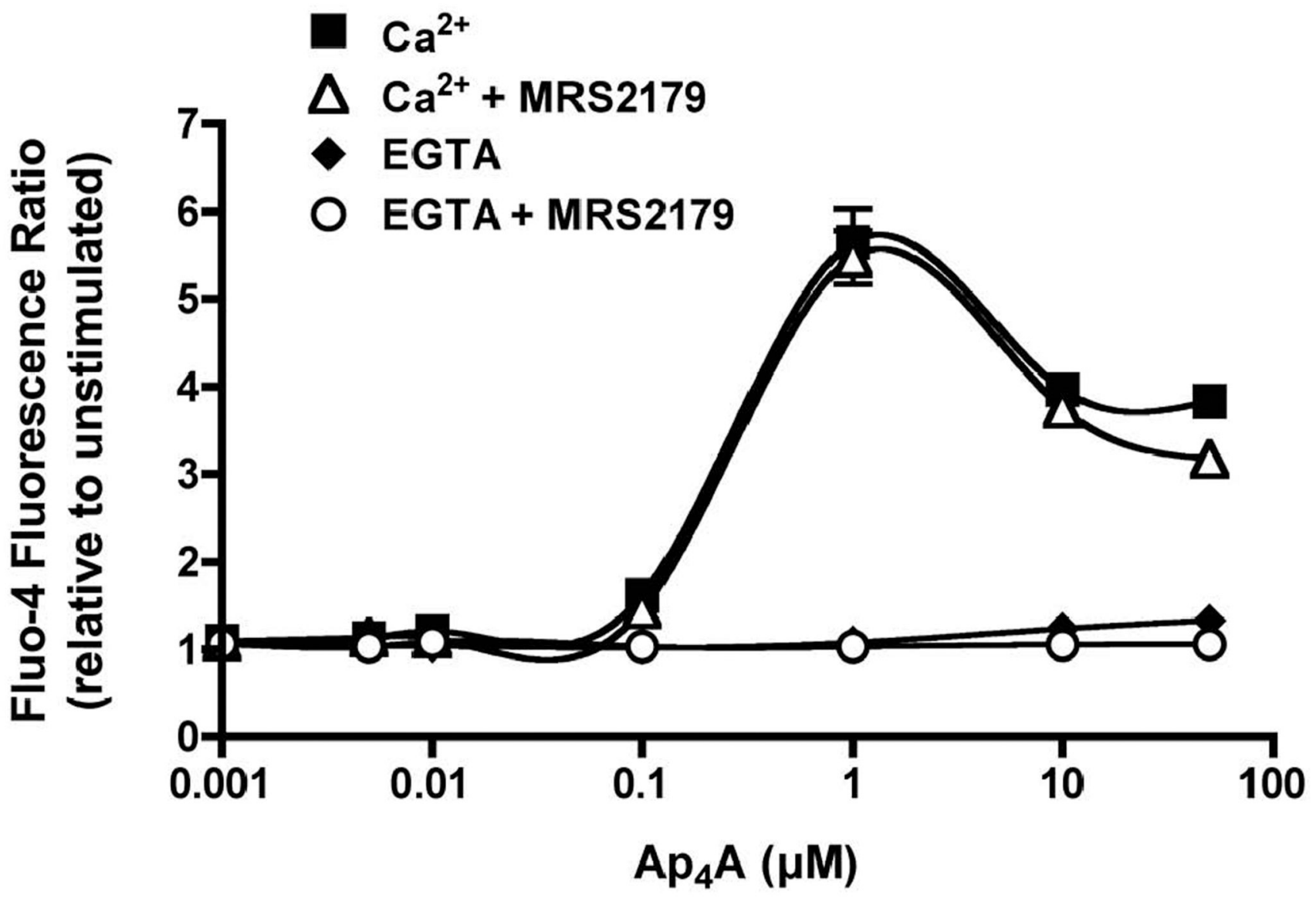

Figure 5. Dose response of $\mathrm{Ap}_{4} \mathrm{~A}$-induced, $\mathrm{P}_{2} \mathrm{X}_{1}$-mediated cytosolic $\mathrm{Ca}^{2+}$ increase. $\mathrm{A}$ The experiments were performed under conditions specific for $\mathrm{P}_{2} \mathrm{X}_{1}$ (see Materials and Methods for details), with the indicated buffers: (匹) $2 \mathrm{mM} \mathrm{Ca}^{2+}$; (४) $1 \mathrm{mM} \mathrm{EGTA,} \mathrm{no} \mathrm{Ca}^{2+}$;

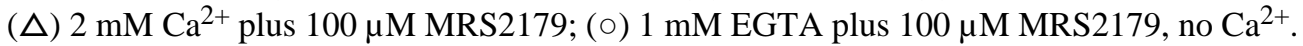
Results are mean \pm SEM, $\mathrm{n}=4$. 


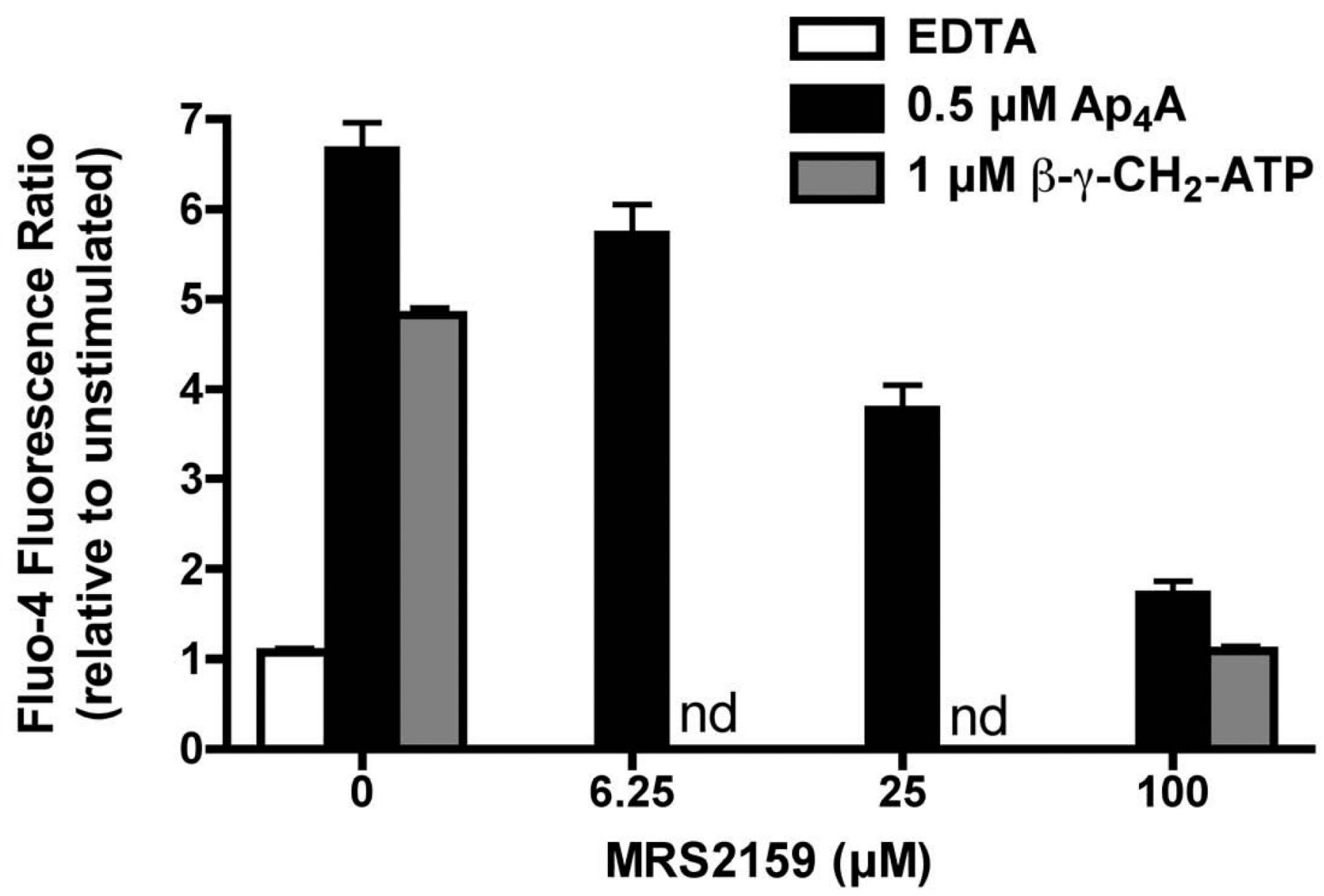

Figure 6. Dose-dependent MRS2159 inhibition of $0.5 \mu \mathrm{M} \mathrm{Ap}_{4} \mathrm{~A}$ - and $1 \mu \mathrm{M} \beta, \gamma-\mathrm{CH}_{2}$-ADP-induced entry of extracellular $\mathrm{Ca}^{2+}$ into platelets

FLUO-4-loaded platelets suspended in $2 \mathrm{mM} \mathrm{Ca}^{2+}$ buffer were stimulated with either $\mathrm{Ap}_{4} \mathrm{~A}$ $0.5 \mu \mathrm{M}$ (black bars) or $1 \mu \mathrm{M} \beta, \gamma-\mathrm{CH}_{2}$-ATP (grey bars) in the presence of $0,6.25,25$, or 100 $\mu \mathrm{M}$ MRS2159. Dependence on extracellular calcium is shown by results of control samples suspended in $2 \mathrm{mM}$ EDTA without $\mathrm{Ca}^{2+}$ and stimulated with $\mathrm{Ap}_{4} \mathrm{~A} 0.5 \mu \mathrm{M}$ (open bar). Results are mean \pm SEM, $n=3$. Abbreviations: EDTA, ethylene diamine tetraacetic acid; nd, not done. 
Table

Summary of $\mathrm{Ap}_{4} \mathrm{~A}$ platelet stimulating and inhibiting activities.

\begin{tabular}{|c|c|c|}
\hline Assay & Ap $_{4}$ A Agonist Activity & $\begin{array}{l}\mathrm{Ap}_{4} \mathrm{~A} \text { Antagonist Activity } \\
\text { (inhibition of ADP } \\
\left.\text { or } \beta, \gamma-\mathrm{CH}_{2}-\mathrm{ATP}\right)^{*}\end{array}$ \\
\hline $\begin{array}{l}\text { Aggregation } \\
\left(\mathrm{P} 2 \mathrm{Y}_{1} \text { and } \mathrm{P} 2 \mathrm{Y}_{12}\right. \\
\text { mediated) }\end{array}$ & no activation at up to $250 \mu \mathrm{M}$ & $\mathrm{IC}_{50} 9.8 \pm 2.8 \mu \mathrm{M}$ \\
\hline $\begin{array}{l}\text { Shape Change } \\
\text { (P2 } \mathrm{Y}_{1} \text { mediated) }\end{array}$ & no activation at up to $250 \mu \mathrm{M}$ & $\mathrm{IC}_{50} \sim 200 \mu \mathrm{M}$ \\
\hline $\begin{array}{l}\mathrm{P} 2 \mathrm{Y}_{1} \text { release of } \\
\text { internal } \mathrm{Ca}^{2+}\end{array}$ & no activation at up to $100 \mu \mathrm{M}$ & $\mathrm{IC}_{50} 40.8 \pm 12.3$ \\
\hline $\begin{array}{l}\text { P2 } \mathrm{Y}_{12} \text {-mediated } \\
\text { VASP }\end{array}$ & maximal at $15.6 \mu \mathrm{M}$ & $\mathrm{IC}_{50}>250 \mu \mathrm{M}$ \\
\hline $\begin{array}{l}\mathrm{P} 2 \mathrm{X}_{1} \text { entry of } \\
\text { external } \mathrm{Ca}^{2+}\end{array}$ & $\mathrm{EC}_{50} \sim 0.3 \mu \mathrm{M}$ (biphasic curve) & No inhibition at $50 \mu \mathrm{M}$ \\
\hline
\end{tabular}

*Ap4A antagonist activity was determined relative to $3 \mu \mathrm{M}$ ADP stimulation of platelet aggregation, shape change, $\mathrm{P} 2 \mathrm{Y}_{1}$ release of internal $\mathrm{Ca}{ }^{2+}$, and P2Y12-mediated VASP and relative to $20 \mu \mathrm{M} \beta, \gamma-\mathrm{CH}_{2}-\mathrm{ATP}$ stimulation of $\mathrm{P} 2 \mathrm{X}_{1}$ entry of external $\mathrm{Ca}^{2+}$. 